\title{
Yeasts in native fruits from Brazilian neotropical savannah: occurrence, diversity and enzymatic potential
}

\author{
Helson Mario Martins do Vale ${ }^{1 *(1)}$, Jefferson Brendon Almeida dos Reis ${ }^{2}$, Marcos de Oliveira ${ }^{2,3}$, Geisianny \\ Augusta Monteiro Moreira ${ }^{2}$ \& Catharine Abreu Bomfim ${ }^{2}$ \\ ${ }^{1}$ Universidade de Brasilia, Instituto de Ciências Biológicas, Departamento de Fitopatologia, Brasilia, DF, Brasil. \\ ${ }^{2}$ Universidade de Brasilia, Instituto de Ciências Biológicas, Programa de Pós-graduação em Biologia \\ Microbiana, Brasilia, DF, Brasil. \\ ${ }^{3}$ Instituto Federal de Educação Ciência e Tecnologia do Norte de Minas Gerais, Salinas, MG, Brasil. \\ *Corresponding author: helson@unb.br
}

VALE, H.M.M., REIS, J.B.A., OLIVEIRA, M., MOREIRA, G.A.M., BOMFIM, C.A. Yeasts in native fruits from Brazilian neotropical savannah: occurrence, diversity and enzymatic potential. Biota Neotropica 21(4): e20201184. https://doi.org/10.1590/1676-0611-BN-2020-1184

\begin{abstract}
Cerrado is the second largest phytogeographic domain in Brazil, with a huge ethnobotany variety, including fruit species that stand out for their economic, industrial, biotechnological and medicinal potential. The objective of this study was to characterize the diversity of culturable yeasts and their potential for the production of hydrolytic enzymes in fruits of 13 species of native plants of the Cerrado in Brazil. Sequencing the 26S rRNA gene identified the isolates. The enzymatic potential was evaluated using specific substrates for the enzymes amylases, cellulases, proteases, and pectinases. Nine of the 13 fruit species analyzed showed yeast growth, totaling 82 isolates, identified in 26 species. The phylum Ascomycota predominated over Basidiomycota. The fruits of Butia capitata presented the highest species richness. Candida and Meyerozyma were the most frequent genera. About $57 \%$ of the isolates were able to produce at least one of the enzymes analyzed. The species Papiliotrema flavescens, Hanseniaspora meyeri, Meyerozyma guilliermondii, and Rhodotorula mucilaginosa produced all the enzymes tested. The results were found to expand the knowledge about the yeast communities present in fruits of the Cerrado native plants, evidencing the presence of species shared among the plants, and their potential for biotechnological use in the future.
\end{abstract}

Keywords: hydrolytic enzymes; Candida; Cerrado domain; Meyerozyma; fruit pulp.

\section{Leveduras em frutos nativos do Cerrado: ocorrência, diversidade e potencial enzimático}

\begin{abstract}
Resumo: O Cerrado é o segundo maior domínio fitogeográfico do Brasil, com grande variedade etnobotânica, incluindo espécies frutíferas que se destacam por seu potencial econômico, industrial, biotecnológico e medicinal. O objetivo deste trabalho foi caracterizar a diversidade de leveduras cultiváveis e seu potencial para a produção de enzimas hidrolíticas em frutos de 13 espécies de plantas nativas do Cerrado brasileiro. O sequenciamento do gene 26S rRNA identificou os isolados. O potencial enzimático foi avaliado utilizando substratos específicos para as enzimas amilases, celulases, proteases e pectinases. Nove das 13 espécies de frutos analisadas apresentaram crescimento de levedura, totalizando 82 isolados, identificados em 26 espécies. O filo Ascomycota predominou sobre Basidiomycota. Os frutos de Butia capitata apresentaram a maior riqueza de espécies. Candida e Meyerozyma foram os gêneros mais frequentes. Cerca de $57 \%$ dos isolados foram capazes de produzir pelo menos uma das enzimas analisadas. As espécies Papiliotrema flavescens, Hanseniaspora meyeri, Meyerozyma guilliermondii e Rhodotorula mucilaginosa produziram todas as enzimas testadas. Os resultados encontrados ampliam o conhecimento sobre as comunidades de leveduras presentes nos frutos das plantas nativas do Cerrado, evidenciando a presença de espécies compartilhadas entre as plantas, e seu potencial para uso biotecnológico no futuro.
\end{abstract}

Palavras-chave: Enzimas hidrolíticas; Candida; Domínio Cerrado; Meyerozyma; Polpa de frutas. 


\section{Introduction}

The Cerrado is the second largest phytogeographic domain in Brazil occupying about 2 million $\mathrm{km}^{2}$ with phytophysiomic formations of tropical fields, savannah, and seasonal forest (Klink, 2005; Buzatti et al. 2018). This biome is considered a biodiversity hotspot characterized by having a high number of endemic vascular plant species (Souza et al. 2016; Buzatti et al. 2018). It is estimated that there are more than 4.400 plants native to this biome and, among this huge ethnobotanical variety, fruit species stand out for their economic, industrial, biotechnological, and medicinal value (Wantzen et al. 2012; Machado et al. 2014; Costas et al. 2018).

Among the native fruit species of the Brazilian Cerrado, some of the most studied and used for economic and biotechnological purposes are the Anacardium humile A.St.-Hil (Cerrado cashew) (Silva et al. 2013; Araújo et al. 2018), Caryocar brasiliense Cambess (pequi) (Paz et al. 2014) and Mauritia flexuosa Lf (buriti) (Castro et al. 2014; Garcia et al. 2015; Pratulea et al. 2019). The fruits of these plant species, besides being rich in nutritional values, are known to present molecules with anti-inflammatory, antioxidant, antimicrobial, thickening, and aromatic properties (Silva et al. 2013; Costas et al. 2018). In addition, to be known for their nutraceutical characteristics, the Cerrado fruits have great economic importance for small farmers and extractivists in the Northwest region of the state of Minas Gerais - Brazil, like the cooperative "Copabase" (www.copabase.org), whose main objective is the commercialization of family and artisanal production products, such as fruit pulps, sweets, cakes, and other food products from the Cerrado fruits (Souza et al. 2018).

Several microbial communities have the ability to colonize the interior of plant organs, known as endophytic microorganisms. The term endophytic concerns to all microorganisms that inhabit the interior of organs, tissues and in the inter-and intracellular space of plant cells in a mutualistic way, and may play crucial roles for the maintenance of plant health or producing plant growth regulators (Liu et al. 2019) and alkaloids that act in the protection of plant tissues against herbivores (Felber et al. 2016). Among these microorganisms, the presence of yeasts in the Cerrado native fruits has been attracting attention because they are important sources of new biotechnological resources (Moreira et al. 2015; Sperandio, et al. 2015; Vale, et al. 2015).

Yeasts represent a portion of the natural microbiota of the plant phyllosphere (leaves, stems, shoots, flowers, and fruits) (Vadkertiová et al. 2012; Ling et al. 2019; Piombo et al. 2020) and more recently has been reported in fruits of the Cerrado native plants such as Eugenia lutescens Cambess, Campomanesia xanthocarpa (O. Berg) and Brosimum gaudichaudii Trécul (Moreira et al. 2015); Byrsonima crassifolia Steud and Eugenia dysenterica DC (Sperandio et al. 2015) and also in fruits of seven more native species of the Cerrado: Ouratea hexasperma Baill, B. gaudichaudii Trécul, Passiflora nitida Kunth, Myrcia tomentosa DC, Byrsonima coccolobifolia Kunt, Guapira graciliflora (Mart. Ex Schmidt) and C. brasiliense Cambess (Coelho et al. 2020). Some of these species have the potential for biological control of post-harvest pathogens, such as Penicillium digitatum in vitro and in vivo tests (Sperandio et al. 2015), emphasizing the importance of knowledge about yeast diversity in the Cerrado native fruits and its biotechnological application.

Yeasts have a high biochemical and physiological versatility, which make them important sources of biomolecule prospecting, similar to enzymes that are commonly used in industrial applications (Carvalho et al. 2013).
Currently, interest in the production of enzymes from microbial sources has increased due to the wide application potential, ranging from the production of bioenergy and biofuels to its application in food, textile and papermaking industries (Romo-Sánchez et al. 2010). However, it is still necessary to search for native yeast species not listed as good producers of active biomolecules. It is important to highlight the need to isolate and characterize yeasts from different habitats, aiming at describing the still unknown diversity, and to verify the biotechnological potential that these microorganisms may present (Romo-Sánchez et al. 2010; Carvalho et al. 2013).

Understanding the importance of the Cerrado bioeconomy, its native plants, and the scarcity of research on yeast diversity in native fruits of this Biome, this study aimed to: a) describe the occurrence, density, and diversity of culturable yeasts in fruits of the Cerrado native plants; and b) evaluate the potential of isolated strains for hydrolytic enzyme production.

\section{Materials and Methods}

\section{Area of study and sampling of fruits}

Samples were collected in the Northwest region of the state of Minas Gerais, in the municipality of Arinos, Brazil (Table 1). Fruits of 13 Cerrado native species were collected, as follows: Anacardium humile Mart., Annona crassiflora Mart., Butia capitata Mart., Caryocar brasiliense Cambess, Eugenia dysenterica DC., Hancornia speciosa Gomes, Hymenaea stigonocarpa Mart. Ex Hayne, Mauritia flexuosa Lf., Passiflora cincinnata Mast., Psidium cattleyanum Sabine, Solanum lycocarpum A.St-Hil, Syagrus oleracea Becc and Talisia esculenta Radlk (Figure S1). Samples of healthy fruits, ripe, without perforations and smashes, were collected, stored at $4^{\circ} \mathrm{C}$, and processed in less than 48 hours after collection.

\section{Isolation and molecular identification}

For the isolation of total yeasts (epiphytic + endophytic), samples of fruits from 13 species of plants were collected, being three different trees for each plant species and three different samples for each tree of the same plant species. Fruits were superficially washed with distilled running water to remove dust and dried naturally at room temperature. Aliquots of $10 \mathrm{~g}$ composed of pulp and peel of each fruit sample, in triplicate, macerated in $100 \mathrm{ml}$ of peptone water $(0.1 \%)$, and then homogenized under agitation at $150 \mathrm{rpm}$ for 30 minutes, and diluted to $10^{-3}$. Aliquots of $100 \mu \mathrm{L}$ were seeded in YM agar $(0.3 \%$ yeast extract; $0.3 \%$ malt extract; $0.5 \%$ peptone; $10 \%$ glucose; $2 \%$ agar; $100 \mathrm{mg}$. $\mathrm{ml}^{-1}$ chloramphenicol) (Kurtzman \& Fell, 1998). The plates were incubated at $28{ }^{\circ} \mathrm{C}$ for 5-7 days. After growth, colony-forming units (CFU) were counted, and isolation in pure cultures was performed from each colony's morphological characteristics. The pure cultures were cryopreserved using YM broth with $25 \%$ glycerol in a freezer at $-80^{\circ} \mathrm{C}$.

DNA was extracted according to modified Kurtzman \& Fell protocol (1998). The isolates were grown in YM broth for 48 hours at $28{ }^{\circ} \mathrm{C}$ under the agitation of $150 \mathrm{rpm}$. Cell lysis was performed using $0.1 \mathrm{~g}$ of glass beads and $200 \mu \mathrm{L}$ of extraction buffer and agitated for 1 minute. For protein precipitation, $200 \mu \mathrm{L}$ of phenol, chloroform, and isoamyl alcohol (25:24:1) was used, and subsequently, the DNA was precipitated using isopropyl alcohol ( 1 hour at $-20^{\circ} \mathrm{C}$ ). The DNA was resuspended in $30 \mu \mathrm{L}$ of Milli-Q water and stored at $-20^{\circ} \mathrm{C}$.

The DNA amplification was performed according to the Kurtzman \& Robnett protocol (1998) using domain D1/D2 of the major ribosomal 
Yeasts in native fruits from brazilian Cerrado.

Table 1. Cerrado native species host plants collected in the municipality of Arinos, Minas Gerais, Brazil.

\begin{tabular}{|c|c|c|c|c|}
\hline Botanical Family & Host species & Popular name & Geographic Coordinates & Date of collection \\
\hline Anacardiaceae & Anacardium humile Mart. & Caju-do-Cerrado & $15^{\circ} 55^{\prime} 01^{\prime \prime} \mathrm{S}$ e $46^{\circ} 6^{\prime} 20^{\prime \prime} \mathrm{W}$ & $08 / 08 / 2014$ \\
\hline Annonaceae & Annona crassiflora Mart. & Araticum & $15^{\circ} 55^{\prime} 01^{\prime \prime} \mathrm{S}$ e $46^{\circ} 6^{\prime} 20^{\prime \prime} \mathrm{W}$ & $03 / 14 / 2014$ \\
\hline Apocynaceae & Hancornia speciosa Gomes & Mangaba & $15^{\circ} 55^{\prime} 01^{\prime \prime} \mathrm{S}$ e $46^{\circ} 6^{\prime} 20^{\prime \prime} \mathrm{W}$ & $03 / 14 / 2014$ \\
\hline Arecaceae & Mauritia flexuosa Lf. & Buriti & $15^{\circ} 51^{\prime} 20^{\prime \prime} \mathrm{S}$ e $45^{\circ} 43^{\prime} 52^{\prime \prime} \mathrm{W}$ & 08/16/2014 \\
\hline Arecaceae & Syagrus oleracea Becc & Coco-guariroba & $16^{\circ} 1^{\prime} 12^{\prime \prime} \mathrm{S}$ e $45^{\circ} 58^{\prime} 39^{\prime \prime} \mathrm{W}$ & $03 / 30 / 2014$ \\
\hline Myrtaceae & Eugenia dysenterica DC. & Cagaita & $15^{\circ} 55^{\prime} 01^{\prime \prime} \mathrm{S}$ e $46^{\circ} 6^{\prime} 20^{\prime \prime} \mathrm{W}$ & $10 / 12 / 2014$ \\
\hline Myrtaceae & Psidium cattleyanum Sabine & Araçá & $15^{\circ} 55^{\prime} 01^{\prime \prime} \mathrm{S}$ e $46^{\circ} 6^{\prime} 20^{\prime \prime} \mathrm{W}$ & $03 / 28 / 2014$ \\
\hline Passifloraceae & Passiflora cincinnata Mast. & Maracujá-do-Cerrado & $16^{\circ} 1$ ' $12^{\prime \prime} \mathrm{S}$ e $45^{\circ} 58^{\prime} 39^{\prime \prime} \mathrm{W}$ & $05 / 19 / 2014$ \\
\hline Sapindaceae & Talisia esculenta Radlk & Pitomba & $15^{\circ} 51^{\prime} 20^{\prime \prime} \mathrm{S}$ e $45^{\circ} 43^{\prime} 52^{\prime \prime} \mathrm{W}$ & $03 / 16 / 2014$ \\
\hline Solanaceae & Solanum lycocarpum A.St-Hil & Lobeira & $15^{\circ} 51^{\prime} 20^{\prime \prime} \mathrm{S}$ e $45^{\circ} 43^{\prime} 52^{\prime \prime} \mathrm{W}$ & 06/09/2014 \\
\hline
\end{tabular}

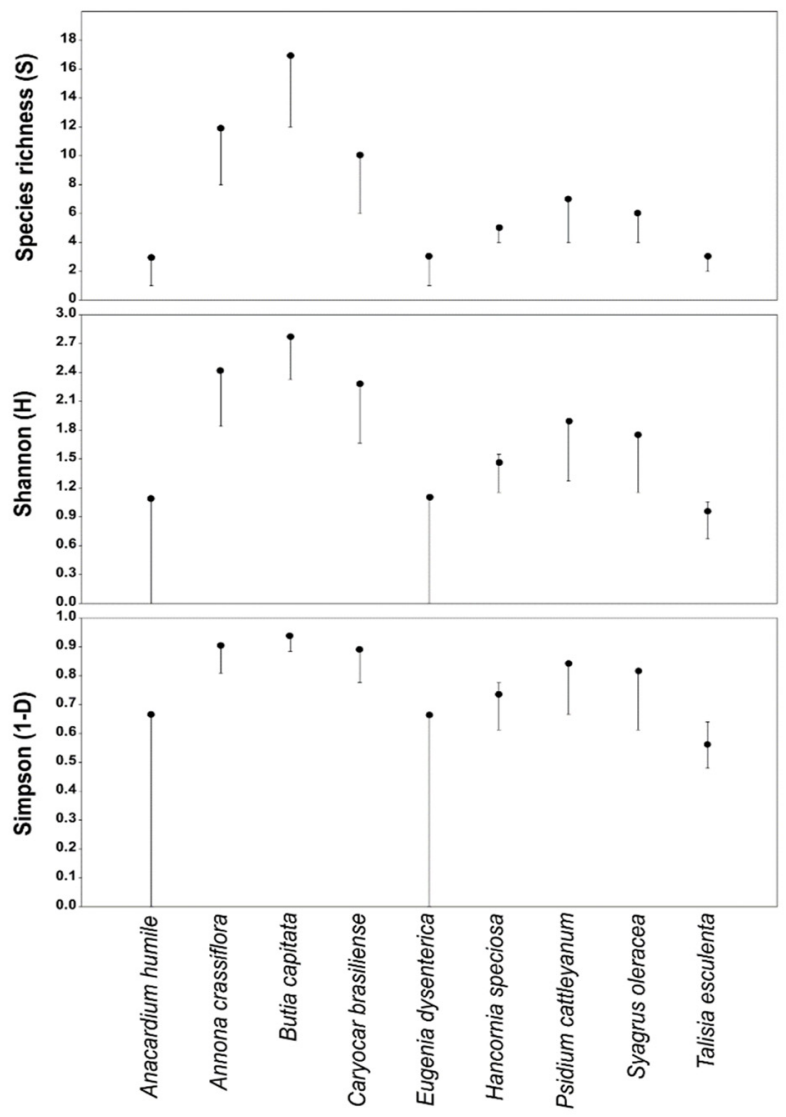

Figure 1. Diversity indexes of yeast communities present in fruits of the Cerrado native plants from the Northwest of Minas Gerais, Arinos, Brazil.

rDNA subunit (LSU) 26S, with the pair of primers: NL1 (5'-GCA TAT CAA TAA GCG GAG GAA AAG-3') and NL4 (5'-GGT CCG TGT TTC AAG ACG G -3') (O'donnel et al. 1993). The PCR reaction was performed with a final volume of $25 \mu 1$, containing $20 \mathrm{pmol}$ of each primer, $1.5 \mathrm{mM} \mathrm{MgCl}_{2}$, and $0.2 \mathrm{mM}$ dNTPs. The thermocycling program consisted of initial denaturation at $94^{\circ} \mathrm{C}$ for 3 minutes, followed by 33 denaturation cycles from $94{ }^{\circ} \mathrm{C}$ to 1 minute, annealing at $56^{\circ} \mathrm{C}$ for 30 seconds, and extension at $72{ }^{\circ} \mathrm{C}$ for 1 minute, and a final extension at 72 ${ }^{\circ} \mathrm{C}$ for 6 minutes.

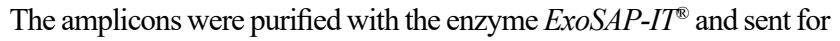
sequencing at the Catholic University of Brasilia (UCB) using the ABI 3130xl
Applied Biosystems sequencer, using the Sanger method (Sanger et al. 1997). The formation of their peaks ascertained the quality of the sequences. These sequences were prepared by removing initial and final noises with the Bio Edit Sequence Alignment Editor version 7.5. After that, they were submitted to the Database of the National Center for Biotechnology Information (NCBI (http://www.ncbi.nlm.nih.gov/), using the program BLASTn. The parameters of choice were lower e-value, greater coverage value, and greater identity. The alignment and phylogenetic analyses were made using the $M E G A$ 6 software ${ }^{\circledR}$ using the Maximum-likelihood Estimation Method Maxim Verisiillability method (Tamura et al. 2013).

The diversity indices (Species richness S, Simpson 1-D, Shannon $\mathrm{H})$ were calculated based on an abundance matrix (isolates versus host plant) using the Past program (version 3.13).

\section{Enzymatic production}

The enzymatic isolates characterization was performed as described in Souza (2008) and Landell (2009) with some modifications. The isolates were cultured in YM broth at $28{ }^{\circ} \mathrm{C}$ until reaching the cell density of $10^{8}$ cells $/ \mathrm{mL}$. The evaluations were carried out using the "cup plate" methodology, where $100 \mu 1$ of the yeast solution were inoculated in a perforation (cup) performed with a Pasteur pipette in triplicate at three equidistant points with a diameter of $6 \mathrm{~mm}$. Culture media containing a specific substrate for each enzyme were used. Amylase production was evaluated in Agar-starch (Agar, 18 g.L $\mathrm{L}^{-1}$; starch, 10 g.L.- ), was cellulases were evaluated in Agar-CMC (Agar, 18 g.. $\mathrm{L}^{-1}$, carboxymethylcellulose, 10 g. $\mathrm{L}^{-1}$ ). The Agar-pectin (Agar, 18 g.L $\mathrm{L}^{-1}$, pectin, $10 \mathrm{~g} . \mathrm{L}^{-1}$ ) was used to detect pectinases and Agar-gelatin-milk (Agar, 18 g.L. $\mathrm{L}^{-1}, 10 \%$ gelatin solution, skim milk $10 \%$ ) for proteases. After a 24-hour incubation period, plates were washed with $0.1 \mathrm{~N}$ iodine solution for amylase analysis, Congo red $0.1 \%$ for cellulase analysis and $5 \mathrm{~N}$ hydrochloric acid for pectinase analysis. No revealing substance was required for protease tests. The formation of degradation halos detected the enzymes and production was expressed by forming the halos (mm).

\section{Results}

\section{Yeast density and diversity}

A total of 82 yeast isolates were recovered from fruits from nine of the 13 hostesses analyzed in this study. Yeast growth was not detected 
in the fruits of four plant species, including S. lycocarpum (Lobeira), $H$. stigonocarpa (Jatobá-do-Cerrado), M. flexuosa (Buriti) and P. cincinnata (Maracujá-do-Cerrado). The host B. capitata (Coquinho-azedo) presented the highest number of isolates (21), while the fruits of S. oleracea (Cocoguariroba) presented the highest population density of yeasts $\left(7.2 \times 10^{4} \mathrm{CFU}\right.$ . $\mathrm{g}^{-1}$ fruit). The fruits of T. esculenta (Pitomba), C. brasiliense (Pequi) and E. dysenterica (Cagaita) presented population densities lower than $1.0 \times 10$ $\mathrm{CFU} \mathrm{g}^{-1}$. The hostesses A. humile (Cajuzinho-do-Cerrado) and E. dysenterica (Cagaita) presented the smallest number of isolates (three isolates) (Table 2).

The highest richness of yeast species (S) was found in the fruits of $B$. capitata, followed by $A$. crassiflora and $C$. brasilienses. The fruits with the lowest species richness were $A$. humile, E. dysenterica, and T. esculenta. The diversity of yeasts in the fruits of plant species, represented by the Shannon (H) and Simpson (1-D) indexes, varied widely from plant to plant (Figure 1). The Shannon and Simpson indexes of B. capitata were 2.8 and 1.0, respectively, thus having the highest species diversity values compared to the other analyzed species. A. crassiflora occupied the second place with Shannon index of 2.4 and Simpson of 0.9 , followed by $C$. brasiliense with Shannon of 2.3 and Simpson of 0.89. T. esculenta presented the lowest values in the Shannon and Simpson indexes.

Among the isolates, 26 yeast species were identified in fruit samples from nine plant species where there was colony growth (Table 3 ). The phylum Ascomycota was predominant, representing $80 \%$ of the isolates distributed in 10 genus: Meyerozyma, Candida, Debaryomyces, Wickerhamomyces, Hanseniaspora, Pichia, Kurtzmaniella, Yarrowia, Eremothecium, and Lodderomyces. Phylum Basidiomycota corresponds to $20 \%$ of the isolates, divided into four genus: Rhynchogastrema, Papiliotrema, Pseudozyma, and Rhodotorula.

The species composition of the culturable yeast communities varied among the different fruits (Figure 2). The species Pichia terricola showed higher relative abundance in the fruits of $H$. speciosa. In the fruits $B$. capitata and $P$. cattleyanum, the species Papiliotrema flavescens and P. terricola showed higher relative abundance.

The genera Candida and Meyerozyma were the most frequent, present in $89 \%$ of the fruits analyzed here. M. caribbica was the species with the highest occurrence, present in five different fruits, and the following plant species: B. capitata (Coquinho-azedo), A. crassiflora (Araticum), H. speciosa (Mangaba), E. dysenterica (Cagaita) and $A$. humile (Caju-Cerrado). The species M. guilliermondii, Debaryomyces nepalensis, Hanseniaspora meyeri and Pichia terricola were isolated in $44.4 \%$ of the fruits analyzed here. The species $D$. fabryi was less frequent here, exclusively in B. capitata fruits.

\section{Enzymatic production}

Of the 82 isolates, $43(52,43 \%)$ isolates produced at least one of the enzymes sought in this study, and 12 isolates produced amylases, 21 isolates produced cellulases, 25 isolates produced proteases, and 18 isolates produced pectinase. The isolates with higher enzymatic production were recovered from the fruits of $B$. capitata, $A$. crassiflora and $S$. oleracea (Table 4$)$. Of the 82 isolates, only $39(47,56 \%)$ did not show the care of the enzymes investigated here, being they of the following species Candida easanensis, Debaryomyces fabryi, D. nepalensis, Hanseniaspora meyeri, Meyerozyma guilliermondii, Pichia terricola, Pseudozyma aphidis, Wickerhamomyces anomalus and $W$. rabaulensis.

Among the enzymes evaluated, the most produced were proteases being present in $52.08 \%$ of the isolates producing the enzymes researched; followed by cellulases, found in $41.66 \%$; pectinases, found in $27.08 \%$ of the isolates; and finally, amylases found in $25 \%$ of the isolates.

Species of the genus Candida are among the best enzymatic producers, with four different species, C. suratensis, C. oleophila, $C$. natalensis and $C$. intermedia; followed by the genus Hanseniaspora, with the species H. opuntiae, H. meyeri, and H. uvarum; and finally, the genus Debaryomyces and Meyerozyma, both with two species. The others genera presented only one species capable of producing one or more of the enzymes tested in this study. Four yeast species produced the four enzymes sought, as P. flavescens, H. meyeri, M. guilliermondii and Rhodotorula mucilaginosa (Table 4). All these yeast species mentioned were isolated in more than three host species, evidencing that these species may be frequent in several Cerrado fruits.

Table 2. Yeast density per gram of fruit (CFU/g. fruit ${ }^{-1)}$ and number of isolates in fruits of Cerrado native host plants, collected in the municipality of Arinos, Minas Gerais, Brazil.

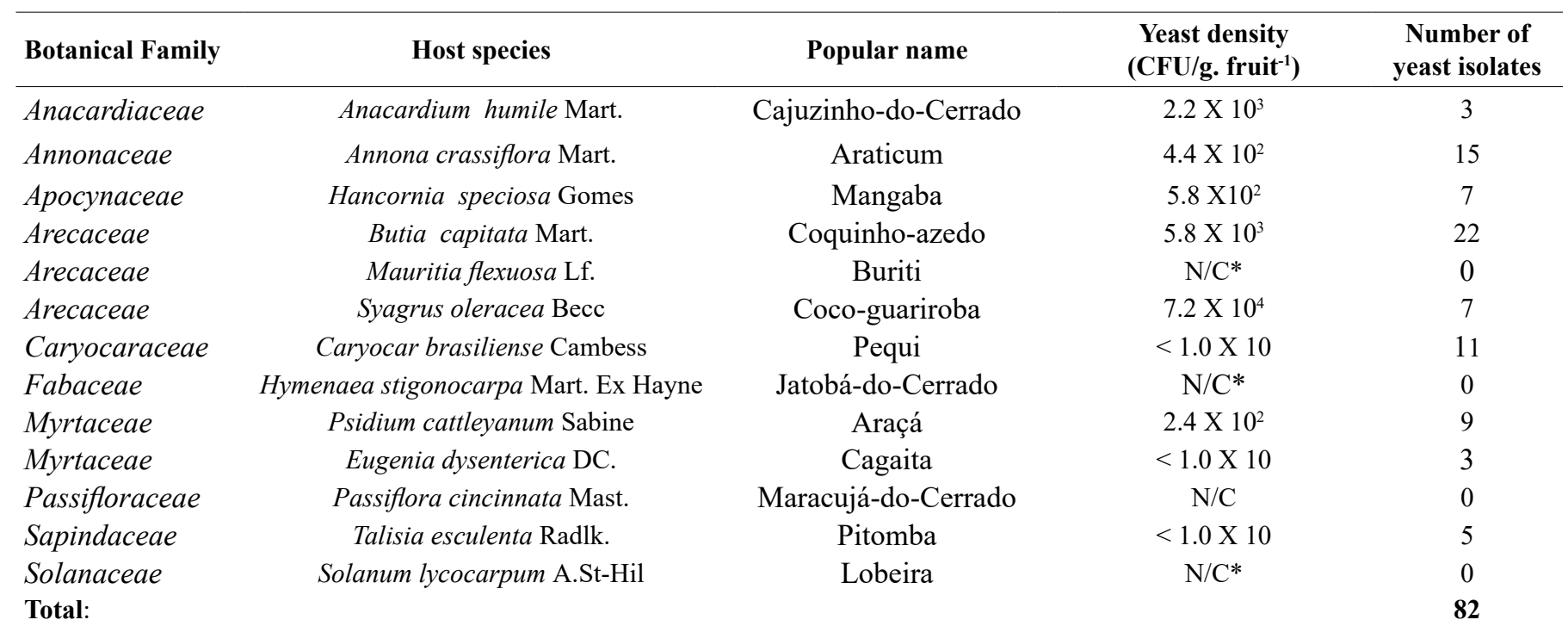

*N/C- There was no growth of yeast colonies. 
Table 3. Inventory of yeast species in fruits of native plant species of the Northwest Cerrado, Arinos, Minas Gerais, Brazil: host species, isolate ID, yeast species, and GenBank match.

\begin{tabular}{|c|c|c|c|c|c|}
\hline BOTANIC FAMILY & HOST SPECIES & ISOLATED ID & SPECIES & GENBANK MATCH & ID (\%) \\
\hline \multirow{3}{*}{ Anacardiaceae } & \multirow{3}{*}{$\begin{array}{c}\text { Anacardium } \\
\text { humile }\end{array}$} & CAJ3 & Debaryomyces nepalensis & JX068681 & 100 \\
\hline & & $\mathrm{CAJ} 2$ & Meyerozyma caribbica & KP797883.1 & 99 \\
\hline & & CAJ4 & Rhynchogastrema complexa & GU321090.2 & 99 \\
\hline \multirow{10}{*}{ Annonaceae } & \multirow{10}{*}{ Annona crassiflora } & ARA5 & Candida easanensis & AY634571.1 & 99 \\
\hline & & ARA26 & Debaryomyces fabryi & KP263777.1 & 99 \\
\hline & & ARA12 & Debaryomyces fabryi & KP263777.1 & 99 \\
\hline & & ARA16 & Hanseniaspora meyeri & FM200038 & 99 \\
\hline & & ARA28 & Hanseniaspora opuntiae & EU386744.1 & 99 \\
\hline & & ARA13 & Lodderomyces sp. & KF830177.1 & 95 \\
\hline & & ARA22 & Meyerozyma caribbica & KP797883.1 & 99 \\
\hline & & ARA6 & Meyerozyma guilliermondii & KM885980 & 99 \\
\hline & & ARA18 & Meyerozyma guilliermondii & KM885980 & 99 \\
\hline & & ARA9 & Wickerhamomyces anomalus & KM978209.1 & 99 \\
\hline \multirow{7}{*}{ Apocynaceae } & \multirow{7}{*}{$\begin{array}{l}\text { Hancornia } \\
\text { speciosa }\end{array}$} & MAN12 & Hanseniaspora meyeri & FM200038 & 99 \\
\hline & & MAN2 & Meyerozyma caribbica & KР797883.1 & 99 \\
\hline & & MA11 & Pichia terricola & KJ506735.1 & 100 \\
\hline & & MAN9 & Pichia terricola & KJ506735.1 & 100 \\
\hline & & MAN1 & Pichia terricola & KJ506735.1 & 100 \\
\hline & & MAN10 & Rhynchogastrema complexa & GU321090.2 & 99 \\
\hline & & MAN3 & Wickerhamomyces rabaulensis & AB858464 & 100 \\
\hline \multirow{14}{*}{ Arecaceae } & \multirow{14}{*}{ Butia capitata } & COQ2 & Candida easanensis & AY634571.1 & 99 \\
\hline & & COQ37 & Candida suratensis & AB500863.1 & 100 \\
\hline & & COQ24 & Debaryomyces nepalensis & JX068681 & 100 \\
\hline & & COQ66 & Meyerozyma guilliermondii & KM885980 & 99 \\
\hline & & COQ35 & Meyerozyma caribbica & KP797883.1 & 99 \\
\hline & & COQ41 & Papiliotrema flavescens & LK023746.1 & 100 \\
\hline & & COQ42 & Papiliotrema flavescens & LK023746.1 & 100 \\
\hline & & COQ40 & Pichia myanmarensis & AB126678.1 & 99 \\
\hline & & COQ61 & Pichia myanmarensis & AB126678.1 & 99 \\
\hline & & COQ46 & Pichia terricola & KJ506735.1 & 100 \\
\hline & & COQ63 & Pichia terricola & KJ506735.1 & 100 \\
\hline & & COQ39 & Rhynchogastrema complexa & GU321090.2 & 99 \\
\hline & & COQ59 & Rhodotorula diobovata & KC442275.1 & 99 \\
\hline & & COQ52 & Yarrowia lipolytica & KF830179.1 & 100 \\
\hline \multirow{7}{*}{ Arecaceae } & \multirow{7}{*}{ Syagrus oleracea } & GUA16 & Candida easanensis & AY634571.1 & 99 \\
\hline & & GUA8 & Hanseniaspora meyeri & FM200038 & 99 \\
\hline & & GUA5 & Hanseniaspora opuntiae & EU386744.1 & 99 \\
\hline & & GUA2 & Meyerozyma guilliermondii & KM885980 & 99 \\
\hline & & GUA3 & Papiliotrema flavescens & LK023746.1 & 100 \\
\hline & & GUA18 & Rhodotorula mucilaginosa & KP760069.1 & 100 \\
\hline & & GUA10 & Rhodotorula mucilaginosa & KP760069.1 & 100 \\
\hline
\end{tabular}


Vale,H.M.M., et al.

continuation...

\begin{tabular}{|c|c|c|c|c|c|}
\hline \multirow{11}{*}{ Caryocaraceae } & \multirow{11}{*}{$\begin{array}{l}\text { Caryocar } \\
\text { brasiliense }\end{array}$} & PEQ16 & Debaryomyces nepalensis & JX06868.1 & 100 \\
\hline & & PEQ2 & Eremothecium sinecaudum & U43391.1 & 99 \\
\hline & & PEQ12 & Hanseniaspora occidentalis & JX103176.1 & 100 \\
\hline & & PEQ9 & Hanseniaspora opuntiae & EU386744.1 & 99 \\
\hline & & PEQ14 & Hanseniaspora uvarum & KM589490 & 100 \\
\hline & & PEQ18 & Lodderomyces sp. & KF830177.1 & 95 \\
\hline & & PEQ3 & Meyerozyma guilliermondii & KM885980 & 99 \\
\hline & & PEQ7 & Meyerozyma guilliermondii & KM885980 & 99 \\
\hline & & PEQ1 & Pichia terricola & KJ506735.1 & 100 \\
\hline & & PEQ8 & Rhynchogastrema complexa & GU321090.2 & 99 \\
\hline & & PEQ5 & Yarrowia lipolytica & KF830179.1 & 100 \\
\hline \multirow{3}{*}{ Myrtaceae } & \multirow{3}{*}{$\begin{array}{c}\text { Eugenia } \\
\text { dysenterica }\end{array}$} & CAG2 & Candida suratensis & AB500863.1 & 100 \\
\hline & & CAG1 & Meyerozyma caribbica & KP797883.1 & 99 \\
\hline & & CAG4 & Rhynchogastrema complexa & GU321090.2 & 99 \\
\hline \multirow{9}{*}{ Myrtaceae } & \multirow{9}{*}{$\begin{array}{c}\text { Psidium } \\
\text { cattleyanum }\end{array}$} & ARAA12 & Candida natalensis & KJ794716.1 & 100 \\
\hline & & ARAA16 & Hanseniaspora meyeri & FM200038 & 99 \\
\hline & & ARAA2 & Papiliotrema flavescens & LK023746.1 & 100 \\
\hline & & ARAA3 & Papiliotrema flavescens & LK023746.1 & 100 \\
\hline & & ARAA15 & Pichia myanmarensis & AB126678.1 & 99 \\
\hline & & ARAA4 & Pichia terricola & KJ506735.1 & 100 \\
\hline & & ARAA5 & Pichia terricola & KJ506735.1 & 100 \\
\hline & & ARAA17 & Rhodotorula diobovata & KC442275.1 & 99 \\
\hline & & ARAA9 & Yarrowia lipolytica & KF830179.1 & 100 \\
\hline \multirow{5}{*}{ Sapindaceae } & \multirow{5}{*}{ Talisia esculenta } & PIT5 & Candida intermedia & KF830176.1 & 99 \\
\hline & & PIT1 & Eremothecium sinecaudum & U43391.1 & 99 \\
\hline & & PIT3 & Lodderomyces sp. & KF830177.1 & 95 \\
\hline & & PIT2 & Lodderomyces sp. & KF830177.1 & 95 \\
\hline & & PIT4 & Lodderomyces sp. & KF830177.1 & 95 \\
\hline
\end{tabular}

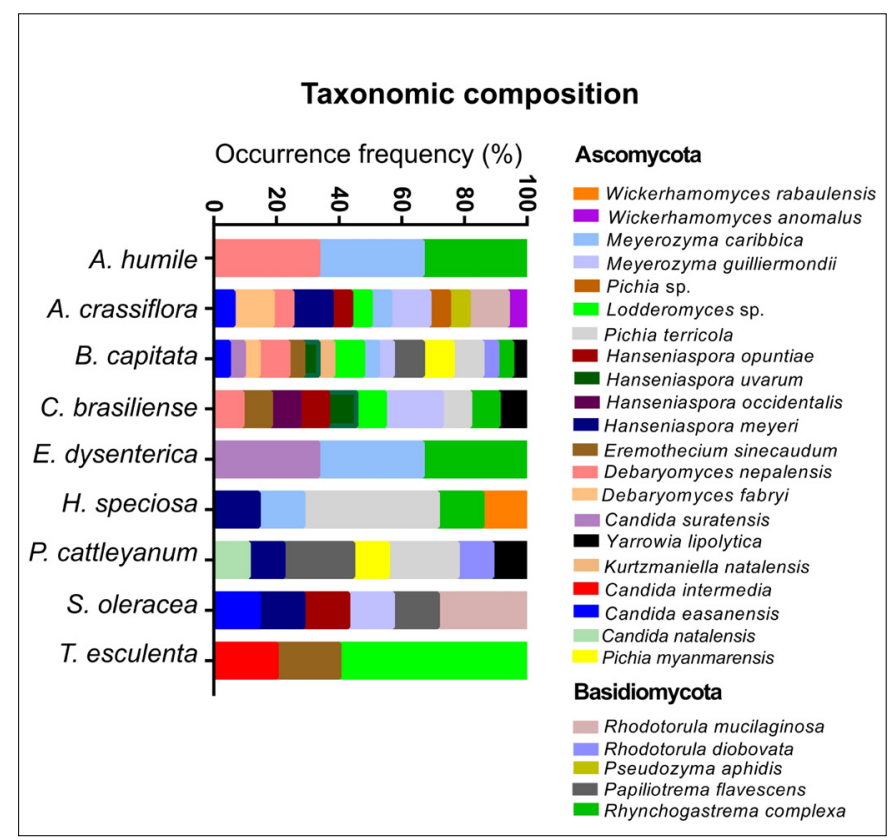

Figure 2. Composition of yeast communities in fruits of the Cerrado native plant species from the Northwest Minas Gerais, Arinos, Brazil.

\section{Discussion}

\section{Yeasts in Cerrado fruits}

The culturable yeast communities diverged among the fruits of the Cerrado native plant species evaluated in this study, regarding cell density and species diversity. The first variable factor among the fruits studied was the density of yeast cells per gram of fruit. The density of microbial cells in the plant may be influenced by abiotic and biotic factors (Hoffman et al. 2008; U'ren et al. 2012), such as seasonality, fruit physiology, host plant ecology, substrate type, fruit morphology, interactions between species, production of 'killer toxins' and competition for substrate (Carvalho et al. 2012; Kusari, et al. 2012; Glushakova \& Chernov, 2010). The degree of fruit ripeness can also influence the density, since the more mature the fruit is, the greater the population density of microorganisms that colonize them (Glushakova \& Kachalkin 2017). Considering that we use only fully ripe fruits, we hypothesized that the variation in population density among these studied fruits is more related to the differences in the characteristics intrinsic to each fruit species. Variations in nutritional composition (type and quality of available nutrients) and other physical and chemical characteristics have already been reported for the ripe fruits that we studied here (Silva et al. 2008; Rocha 2011; Fujita 2012 ).

A high population density of yeasts does not always reflect a greater richness of species (Isaeva et al. 2010). We observed these differences in fruits the A. humile, which presented three yeast species and $2.2 \times 10^{3}$ $\mathrm{CFU} \mathrm{g}{ }^{-1}$, and fruits of $C$. brasiliense, which presented 11 yeast species and $<1.0 \times 10 \mathrm{CFU} \mathrm{g}^{-1}$. The diversity of yeast communities is also influenced by biotic and abiotic factors (Hoffman et al. 2008; U'ren et al. 2012; Glushakova \& Chernov, 2010; Jindamorakot, 2004). Another factor that could interfere in diversity is the mutualistic relationship between microorganisms and plants. The characteristics of the type of colonized tissue can act by selecting the species that would colonize there (Ren et al. 2016; Dhayanithy et al. 2019; Ling et al. 2020). Therefore, we believe that the nutritional characteristics of fruits (quality and availability of nutrients) may be the main factor influencing the richness and abundance of culturable fruit yeast population. 
Table 4. Results of amylase, cellulase, protease, and pectinase production tests by yeast isolates of native fruits from the Northwest Cerrado of Minas Gerais, Arinos, Brazil.

\begin{tabular}{|c|c|c|c|c|c|c|}
\hline SPECIES & PHYLUM & ISOLATE ID & AMYLASE & CELLULASE & PROTEASE & PECTINASE \\
\hline Candida intermedia & Ascomycota & PIT5 & - & - & + & - \\
\hline Candida suratensis & Ascomycota & COQ37 & - & - & + & + \\
\hline Candida suratensis & Ascomycota & CAG2 & - & - & ++ & - \\
\hline Debaryomyces fabryi & Ascomycota & ARA12 & - & - & - & + \\
\hline Debaryomyces nepalensis & Ascomycota & ARA21 & + & - & - & + \\
\hline Debaryomyces nepalensis & Ascomycota & COQ24 & + & + & + & - \\
\hline Eremothecium sinecaudum & Ascomycota & COQ11 & ++ & ++ & ++ & - \\
\hline Hanseniaspora meyeri & Ascomycota & ARA16 & - & + & - & + \\
\hline Hanseniaspora meyeri & Ascomycota & ARAA16 & + & + & - & + \\
\hline Hanseniaspora opuntiae & Ascomycota & GUA5 & ++ & + & - & - \\
\hline Hanseniaspora opuntiae & Ascomycota & ARA28 & + & + & - & - \\
\hline Hanseniaspora uvarum & Ascomycota & COQ13 & - & - & + & - \\
\hline Meyerozyma caribbica & Ascomycota & CAG1 & - & + & + & - \\
\hline Meyerozyma guilliermondii & Ascomycota & GUA2 & - & + & + & + \\
\hline Meyerozyma guilliermondii & Ascomycota & ARA6 & - & + & - & - \\
\hline Meyerozyma guilliermondii & Ascomycota & COQ66 & - & - & - & ++ \\
\hline Pichia myanmarensis & Ascomycota & COQ40 & - & - & + & - \\
\hline Pichia terricola & Ascomycota & COQ63 & - & + & + & - \\
\hline Pichia terricola & Ascomycota & MA11 & - & - & ++ & ++ \\
\hline Pichia terricola & Ascomycota & MAN9 & - & + & + & + \\
\hline Pichia terricola & Ascomycota & MAN1 & - & + & + & + \\
\hline Pichia sp. & Ascomycota & ARA3 & - & + & - & - \\
\hline Pichia sp. & Ascomycota & ARAA15 & + & - & - & - \\
\hline Yarrowia lipolytica & Ascomycota & PEQ5 & ++ & - & - & - \\
\hline Rhodotorula diobovata & Basidiomycota & ARAA17 & - & - & + & + \\
\hline Rhodotorula diobovata & Basidiomycota & COQ59 & - & - & + & + \\
\hline Rhodotorula mucilaginosa & Basidiomycota & GUA18 & - & ++ & + & + \\
\hline Rhodotorula mucilaginosa & Basidiomycota & GUA10 & ++ & + & ++ & ++ \\
\hline Rhodotorula mucilaginosa & Basidiomycota & ARA31 & - & - & + & - \\
\hline Rhodotorula mucilaginosa & Basidiomycota & ARA23 & - & - & + & - \\
\hline
\end{tabular}

(-) absence, (+) halo up to $19 \mathrm{~mm}$ and $(++)$ halo $\geq 20 \mathrm{~mm}$.

A total of 82 isolates of yeasts were recovered from the fruits, with a predominance of Ascomycota yeasts. Our results are in agreement with the literature because fruits have a higher predominance of the phylum Ascomycota because it is a habitat rich in simple carbohydrates (Trindade et al. 2008; Negri et al. 2019; Ren et al. 2019) easily assimilated as a carbon source by yeasts (Carvalho et al. 2006). Also, it is already recognized that ascomycetous yeasts tend to predominate within plant tissues (Sperangio et al. 2015), while basidiomycetes are reported in the phylloplane, as they have adaptations to survive this environment, such as the ability to metabolize more carbohydrate sources complexes from the plant cell wall and produce pigments used for protection against ultraviolet rays ( $\mathrm{Li}$ et al. 2020; Coelho et al. 2020).
Twenty-four yeast species were found, many of them present in more than one fruit species (Table 2). The genus Candida (Ascomycota) was the most frequent with 11 isolates. A higher frequency of the genus Candida has been observed in fruits of the Cerrado (Coelho et al. 2020). Studies to identify fungi in the Cerrado native fruits using a methodology similar to that used in this study have already been carried out, and many of the yeast species described here have not been reported in these fruits or other fruits (Sperandio et al. 2015; Coelho et al. 2020). Our results corroborate the findings of Sperandio (2015), who described the fruit and foliar yeast communities of Byrsonima crassifolia (Murici) and $E$. dysenterica (Cagaita), identifying the species $M$. guilliermondii and $R$. mucilaginosa in common among the those fruits studied. Meanwhile, 
for $E$. dysenterica we have also identified the species $C$. suratensis and Rhynchogastrema complexa, showing new reports of yeast species colonizing these fruits.

In four plant species analyzed in this study, yeast growth was not detected in fruits. The absence of endophytic colonization yeasts in the fruits of Passiflora cincinnata can be explained by the presence of antifungal proteins in the fruits' pulp of the genus Passiflora (Jagessar et al. 2017; He et al. 2020). The antifungal activity of this genus seems to be restricted to pulp and seeds since Coelho et al. (2020) reported the presence of 4 yeast genera colonizing the fruit surface of $P$. nitida and also failed to obtain endophytic isolates. Silva (2017) reported the occurrence of yeasts colonizing the phylloplane of $P$. incarnata. The reasons for the absence of growth in the species Solanum lycocarpum, Hymenaea stigonocarpo, and Mauritia flexuosa do not seem to be linked to the substrate offered yeasts, since the fruits of $S$. lycocarpum present a large amount of carbohydrate and those of M. flexuosa large amount of lipid (Negri et al. 2016). Many studies have demonstrated the antimicrobial potential of H. stigonocarpa (Barbosa et al. 2015; Dimech et al. 2013; Martines et al. 2015), and M. flexuosa (Lima et al. 2006; Batista et al. 2012). These reports may explain the absence of yeasts in these fruits and present information that justifies investigating the phytomedical potential of these plants' products.

The absence of yeasts in fruits of these four plant species may suggest and/or reinforce the hypothesis that they are important sources of biological resources with potential for the production of molecules with antimicrobial action, mainly antifungal. The biotechnological potential of these Cerrado native plants aiming at the development of products for the control of pathogenic fungi deserves to be investigated in future studies. The fruit extract of $S$. lycocarpum (Lobeira) has already shown efficacy against harmful organisms such as the pathogen Leishmania infantum (Clementino et al. 2018) and the parasites Haemonchus contortus (Oliveira, 2013) and cytostostomines (Cyathostominae) (Souza, 2011). In contrast, the leaf extract of $M$. flexuosa demonstrated anti bactericidal activity against the pathogen Pseudomonas aeruginosa (Koolen et al. 2013).

\section{Production of enzymes by yeasts from the Cerrado native fruits}

Of the 82 yeast isolates recovered in this study, $48(60 \%$ of the total) produced one or more of the enzymes studied (cellulase, protease, amylase, and pectinase). A wide variety of molecules and enzymes synthesized by different fungi species have been described (Li et al. 2016). In general, it can be said that fungi colonize environments with low nutrient availability, and as a result, they can present a wide variety of enzyme profiles, such as pectinases, amylases, cellulases, lipases, and protease (Mendes, 2010).

The production of hydrolytic enzymes has been reported as a common trait in plant-associated yeasts. Results similar to those obtained in this study were observed in yeast community (endophytic and epiphytes) isolated from bromeliad, where $40 \%$ to $60 \%$ presented amylolytic, cellulolytic, and proteolytic potential, stand out as producers of the exoenzymes species of Candida, Debaryomyces, Metschnikowia, Pichia, Zygosaccharomyces, Cryptococcus, Fellomyces, Kockovaella, Rhodotorula, Sporobolomyces, Tremella, Aureobasidium, Itersonilia and Tilletiopsis (Landell et al. 2006). Among the yeast species isolated in this study, yeasts from the genera Candida, Debaryomyces, Hanseniaspora, Kloeckera, Lodderomyces, Pichia, and Rhodotorula, are known for the diversity of synthesized enzymes and are used for the production of enzymes of industrial interest and in fermentative processes (Pretorius, 2000; Buzzini et al. 2002; Coutinho et al. 2013; Kot et al. 2016).

Among the yeast species evaluated, five produced the four enzymes. Few studies report the variety of enzymes produced by the yeasts $P$. flavescens, Hanseniaspora meyeri, M. guilliermondii, and $R$. mucilaginosa; however, these species of fungi are found in the soil, in rocks, in tree trunks, and because they colonize the most diverse environments, they are capable of synthesizing a wide variety of enzymes (Wirth, 2011; Andrade et al. 2012). Despite the need for more time for growth, the genus Hanseniaspora can produce proteases and glycolytic enzymes in larger quantities (Fleet, 2008; Comitini et al. 2011). Strains of species M. guilliermondii have been considered a great candidate for the biotechnological production of enzymes (Atzmüller et al. 2020).

The predominance of enzymatic groups varied among yeast species. Proteolytic enzymes were found in 25 isolates, thus representing the predominant enzymatic group. Several factors interfere in the enzymatic production of proteases, such as temperature, $\mathrm{pH}$, the concentration of the substrate used, and the metabolism linked to the cell division process (Neves, 2006; Molnárová et al. 2014). Cellulolytic enzymes were found in 21 isolates, and it is known that cellulase production is among wild yeasts (Buzzini et al. 2002; Mendes et al. 2012). The production of pectinases occupied the third place in the number of isolated producers, with 18 isolates, and the degree of maturation of the fruits may have interfered in this result since pectin is a polysaccharide that is part of the cell wall that is depolymerizing with the ripening of the fruits (Trindade 2002; Paiva, 2009). Amylases were the least produced enzymes, which may be related to low starch use as a carbon source (Alberto et al. 2016). Another justification for the low production of amylases among the isolates in this study is that, according to Onofre (2015), these enzymes are produced mainly by saprophytic basidiomycetes filamentous fungi.

The low hydrolytic activities of fungi isolated from tropical regions can be observed due to the difficulties of visualization of these enzymes' production in a solid medium since fungi require a longer period to develop (Orlandelli et al. 2015; Dantas et al. 2017). Although some authors suggest a longer incubation time for evaluating hydrolytic activity in fungi, Marta et al. (2015) obtained positive results for fungal amylase production in a short incubation time (five days), similar to that used in this study. Another important point to be raised about the low enzyme production is that the diffusion of the enzyme and, consequently, the diameter of the hydrolysis halo are influenced by the molecular mass that the enzyme has, which can hinder or even prevent its diffusion in agar (Alberto et al. 2016). Thus, the enzymatic activity index can be considered low or non-existent, even if there is large enzymatic production by the microorganism.

To our knowledge, this study contributes to numerous unpublished findings. There were no reports yet of yeast associated with fruits such as, A. crassiflora (Araticum), S. oleracea (Coco-guariroba), B. capitata (Coquinho-azedo), H. speciosa (Mangaba), T. esculenta (Pitomba), S. lycocarpum (Lobeira), H. stigonocarpa (Jatobá-do-Cerrado), and P. cincinnata (Maracujá-do-Cerrado), the results of this study is unprecedented both in the analysis of their occurrence colonizing plant organs of the Cerrado biome, the identification of yeasts and their enzymatic potential. 


\section{Supplementary Material}

The following online material is available for this article:

Figure S1 - Fruits harvested for analysis: Passiflora cincinnata (A), Eugenia dysenterica (B), Mauritia flexuosa (C), Hymenaea stigonocarpa (D), Solanum lycocarpum (E), Caryocar brasiliense (F), Annona crassiflora (G), Psidium cattleyanum (H), Butia capitata (I), Syagrus oleracea (J), Hancornia speciosa (K), Talisia esculenta (L) e Anacardium humile (M).

\section{Acknowledgments}

We acknowledge the COPABASE employees who helped us collect the fruit samples. This study was financed in part by the Coordenação de Aperfeiçoamento de Pessoal de Nível Superior - Brasil (CAPES) - Finance Code 001.

\section{Author Contributions}

Helson Mario Martins do Vale: substantial contribution to the conception and design of the study; contribution to data analysis and interpretation; contribution to the preparation of the manuscript; contribution to critical review, adding intellectual content.

Jefferson Brendon Almeida dos Reis: contribution to data analysis and interpretation; contribution to the preparation of the manuscript; contribution to critical review, adding intellectual content.

Marcos de Oliveira: substantial contribution to the conception and design of the study; contribution to data collection; contribution to data analysis and interpretation; contribution to critical review, adding intellectual content.

Geisianny Augusta Monteiro Moreira: contribution to data analysis and interpretation; contribution to the preparation of the manuscript; contribution to critical review, adding intellectual content.

Catharine Abreu Bomfim: contribution to data analysis and interpretation; contribution to the preparation of the manuscript; contribution to critical review, adding intellectual content.

\section{Conflicts of Interest}

The authors declare that they have no conflict of interest related to the publication of this manuscript.

\section{References}

AGIZZIO, AP et al 2003. A 2 S albumin-homologous protein from passion fruit seeds inhibits the fungal growth and acidification of the medium by Fusarium oxysporum. Rev. Arch Biochem Biophys. 15;416(2):188-95.

ALBERTO, RN., COSTA, AT., POLONIO, JC., SANTOS, MS., RHODEN, SA., AZEVEDO, JL., PAMPHILE, JA 2016. Extracellular enzymatic profiles and taxonomic identification of endophytic fungi isolated from four plant species. Genet Mol Res. 3;15(4): 359-366.

ARAÚJO, S et al 2018. Aplicações farmacológicas e tecnológicas da goma do cajueiro (Anacardium occidentale l.) - um produto obtido da flora brasileira Rev. Gestão Inovação e Tecnologias. 8. 4292-4305.

ASCHEHOUG, ET., METLEN, KL., CALLAWAY, RM., NEWCOMBE, G 2012. Fungal endophytes directly increase the competitive effects of an invasive forb. Ecology. 93(1):3-8.
ATZMÜLLER, D., ULLMANN, N., ZWIRZITZ, A 2020. Identificação de genes envolvidos no metabolismo da xilose de Meyerozyma guilliermondii e sua engenharia genética para aumento da produção de xilitol. AMB Express. 10 (1): 78: 1-12.

BARBOSA, JAM., MELO, DLFM., ALMEIDA, FTC., TRINDADE, RC 2015. Estudo comparativo da susceptibilidade de isolados clínicos de Cryptococcus neoformans (Sanfelice, 1895) frente a alguns antifúngicos de uso hospitalar e extratos vegetais obtidos de plantas medicinais da região semiárida sergipana. Rev. Bras. Plantas Med. 17: 120-132.

BORGES, RM et al. 2020 Aspectos físico-químicos de genótipos de Passiflora alata Curtis. Braz. J. Food Technol. 23: 1-10.

BUZZINI, P., MARTINI, A 2002. Extracellular enzymatic activity profiles in yeast and yeast-like strains isolated from tropical environments. J Appl Microbiol. 93(6):1020-1025.

CARROLL, G., PETRINI, O 1983. Patterns of Substrate Utilization by Some Fungal Endophytes from Coniferous Foliage. Mycologia. 75(1): 53-63.

CARVALHO, F., SOUZA, FA., CARRENHO, R., MOREIRA, FMS., JESUS, EC., FERNANDES, GW 2012. The mosaico f habitats in the high-atitude Brazilian rupestrian fields is a hotspot for arbuscular mycorrhizal fungi. Applied Soil Ecology, 52: 9-19.

CLEMENTINO, LC 2018. In vitro activities of glycoalkaloids from the Solanum lycocarpum against Leishmania infantum. Revista Brasileira de Farmacognosia. 28(6): 673-677.

COELHO, LGF et al. 2020. Yeast Communities Structure in Fruits of Native plant species of Brazilian Cerrado. Revista de Biologia Neotropical. 2020 17. 35-46.

COMITINI, F., GOBBI, M., DOMIZIO, P., ROMANI, C., LENCIONI, L., MANNAZZU, I., CIANI, M 2011. Selected non-Saccharomyces wine yeasts in controlled multistarter fermentations with Saccharomyces cerevisiae. Food Microbiology. 28: 873-882.

COSTA, JCF., HOSCHEID, J 2018. Phychochemical profile and evaluation of antimicrobial activity of aqueous and ethanolic extracts of Cecropia pachystachya leaves. Revista Fitos. Rio de Janeiro. 12(2): 175-185.

DANTAS, PVP 2017. Prospecção biotecnológica de fungos endofíticos de bambu (Bambusa vulgaris) micropropagado na produção de enzimas e atividade antimicrobiana. Dissertação de mestrado em Saúde Humana e Meio Ambiente, Universidade Federal de Pernambuco, Pernambuco, Brasil.

DESHMUKH, SK., GUPTA, MK., PRAKASH, V., SAXENA, S 2018. Endophytic Fungi: A Source of Potential Antifungal Compounds. Jornal Fungi (Basel). 4 (77): 1-42

DHAYANITHY, G., SUBBAN K., CHELLIAH, J 2019. Diversidade e atividades biológicas de fungos endofíticos associados com Catharanthus roseus. BMC Microbiol. 19 (1): 1-14.

FÁVARO, LCL., POLETTO, CM 2013. Bioprospecção e melhoramento genético de fungos para produção de enzimas aplicadas em biocombustíveis. In: MACHADO, C. M. M. (Ed.). Microrganismos na produção de biocombustíveis líquidos. Brasília, DF: Embrapa Agroenergia, p. 35-79.

FERREIRA, MC et al. 2017. Antimycobacterial and antimalarial activities of endophytic fungi associated with the ancient and narrowly endemic neotropical plant Vellozia gigantea from Brazil. Mem. Inst. Oswaldo Cruz, Rio de Janeiro. 112(10): 692-697.

FLEET, GH et al. 2008. Wine yeasts for the future. FEMS Yeast Res. 8(7): 979-995.

FUJITA, L. F. F. Caracterização química, microbiológica e farmacognóstica da polpa de coquinho-azedo (Butia capitata (Mart) Becc) produzida em Arinos-MG. São Paulo, 2012. 44 f. Dissertação (Mestrado) - Universidade Estadual Paulista- USP.

GALLEGO, JB et al. 2011. Exploring the yeast biodiversity of green table olive industrial fermentations for technological applications. Int J Food Microbiol. 147(2):89-96.

GARCIA, L, BECKER, F., \& DAMIANI, C 2015. Néctar de buriti (Mauritia flexuosa): a bebida funcional do Cerrado. Revista Verde de Agroecologia e Desenvolvimento Sustentável, 10(1): 263 - 268. 
GLUSHAKOVA, AM., KACHALKIN, AV 2017. Leveduras endofíticas em frutos de Malus domestica e Pyrus communis sob impacto antropogênico. Microbiology. 86: 128-135.

GLUSHAKOVA, AM., CHERNOV, IVAN 2010. Seasonal dynamics of the structure of epiphytic yeast communities. Microbiology. 79: 830-839.

GOMES, SO et al. 2015. Technological forecasting: potential of use pequizeiro (Caryocar spp.). GEINTEC. 5(1): 1617-1625.

GONÇALVES, APP et al. 2017. Caracterização fitoquímica e atividade antimicrobiana de extratos de Solanum subinerme (Solanaceae). Revista Brasileira De Pesquisa Em Saúde/Brazilian Journal of Health Research. 18(2): 8-16.

GUERREIRO, MA, et al. 2018. Transient leaf endophytes are the most active fungi in 1-year-old beech leaf litter. Fungal Diversity. 89: 237-251.

HOFFMAN, MT., ARNOLD, AE 2008. Geographic locality and host identity shape fungal endophyte communities in cupressaceous trees. Mycological Research. 112: 331-344.

ISAEVA, OV., GLUSHAKOVA, AM., GARBUZ, SA., KACHALKIN, AV., CHERNOV, IIU 2010 Endophytic yeast fungi in plant storage tissues. Izv Akad Nauk Ser Biol. 1:34-43.

JINDAMORAKOT, S et al. 2004. Candida easanensis sp. nov., Candida pattaniensis sp. nov. and Candida nakhonratchasimensis sp. nov., three new species of yeasts isolated from insect frass in Thailand. J Gen Appl Microbiol. 50(5):261-269.

KLINK, CA \& MACHADO, RBA 2005. Conservação do Cerrado Brasileiro. Megadiversidade. Belo Horizonte. 1: 147-155.

KOOLEN, HHF., SILVA, FMA., GOZZO, FC., SOUZA, AQL., SOUZA, ADL 2013. Antioxidant, antimicrobial activities and characterization of phenolic compounds from buriti (Mauritia flexuosa L. f.). UPLC-SI-MS/MS Food Res Int, 51: 467-473.

KOT, AM., BŁAŻEJAK, S., KURCZ, A., GIENTKA, I., KIELISZEK, M 2016. Rhodotorula glutinis-potential source of lipids, carotenoids, and enzymes for use in industries. Appl Microbiol Biotechnol. 100(14):6103-6117.

KUMAR, A., NARAYANI, M., SUBANTHINI, A., JAYAKUMAR, M 2011. Antimicrobial Activity and Phytochemical Analysis of Citrus Fruit Peels -Utilization of Fruit Waste. International Journal of Engineering Science and Technology. 3: 5414-5421.

KUSARI, S et al. 2012. Chemical Ecology of Endophytic Fungi: Origins of Secondary Metabolites. Chemistry \& Biology. 19(7): 792-798.

LANDELL, MF., MAUTONE, JN., VALENTE, P 2006. Biodiversity Of Yeasts Associated To Bromeliads In Itapuã Park, Viamão/Rs . BIOCIÊNCIAS, Porto Alegre, v. 14, n. 2, p. 144-149.

LI, P., WU, Z., LIU, T., WANG, Y 2016. Biodiversity, Phylogeny, and Antifungal Functions of Endophytic Fungi Associated with Zanthoxylum bungeanum. Int J Mol Sci. 17(9):1541-1565.

LI, AH et al. 2020. Diversity and phylogeny of basidiomycetous yeasts from plant leaves and soil: Proposal of two new orders, three new families, eight new genera and one hundred and seven new species. Stud Mycol. 96: 17-140.

LIMA, IO et al. 2006. Atividade antifúngica de óleos essenciais sobre espécies de Candida. Rev. bras. farmacogn., João Pessoa. 16(2): 197-201.

LING, L., LI, Z., JIAO, Z., ZHANG, X., MA, W., FENG, J., ZHANG, J \& LU, L 2019 Identification of Novel Endophytic Yeast Strains from Tangerine Peel. Curr Microbiol. 76(9):1066-1072.

LING, L et al. 2020. A potentially important resource: endophytic yeasts. World J Microbiol Biotechnol. 236(8):110.

LIU H., CARVALHAIS, LC., CRAWFORD, M., SINGH, E., DENNIS, PG., PIETERSE, CMJ., SCHENK, PM 2017. Valores internos da planta: Diversidade, colonização e benefícios de bactérias endofíticas. Front Microbiol. 8: 2552-2569.

LUMYONG, S., LUMYONG, P., MCKENZIE, EH., HYDE KD 2002. Enzymatic activity of endophytic fungi of six native seedling species from Doi Suthep-Pui National Park, Thailand. Can J Microbiol. 48(12):1109-12.

MACHADO, N., AQUINO, B., \& NEVES, G 2014. Espécies nativas de plantas frutíferas em uma área de Cerrado em Mato Grosso, Brasil. Rev. Monografias Ambientais. 14. 3306-3315.
MACHADO, RB et al. 2008. Caracterização da fauna e flora do Cerrado. In: FALEIRO, F. G.; FARIA NETO, A. L. (Ed.) Savanas: desafios e estratégias para o equilíbrio entre sociedade, agronegócio e recursos naturais. Planaltina, DF: Embrapa Cerrados; Brasília, DF: Embrapa Informação Tecnológico, 2008. p. 285-300.

MARTA, MGS et al. 2015. Screening of Amazon fungi for the production of hydrolytic enzymes. African Journal of Microbiology Research. 9: 741-748.

MENDES TD, RODRIGUES A, DAYO-OWOYEMI I, MARSON FA, PAGNOCCA FC 2012. Generation of Nutrients and Detoxification: Possible Roles of Yeasts in Leaf-Cutting Ant Nests. Insects. 17;3(1):228-245.

MESTER T \& TIEN M 2000. Oxidation mechanism of ligninolytic enzymes involved in the degradation of environmental polluants. Int Biodeterior Biodegradation. 46: 51-59.

MOLNÁROVÁ J, VADKERTIOVÁ R, STRATILOVÁ E 2014. Extracellular enzymatic activities and physiological profiles of yeasts colonizing fruit trees. J Basic Microbiol. 1: 74-84.

MONTEIRO, MGA., MIRANDA, SE \& VALE, HMM 2016. Leveduras associadas a frutos de plantas nativas do Cerrado: Eugenia lutescens Cambess, Campomanesia xanthocarpa (Mart.) O. Berg e Brosimum guadichaudii. Tréc. Revista De Biologia Neotropical / Journal of Neotropical Biology, 12(2), 104-111.

MOREIRA, RD, et al. 2013. In vitro trypanocidal activity of solamargine and extracts from Solanum palinacanthum and Solanum lycocarpum of brazilian Cerrado. An. Acad. Bras. Ciênc. 85(3): 903-907.

NEGRI, TC., BERNI, PRA., GUIDOLIN, S., CANNIATTI-BRAZACA, SGC 2016. Valor nutricional de frutas nativas e exóticas do Brasil. Ver. Brasileira Biosaúde, Londrina, Paraná. 18(2): 83-97.

NEVES KC et al 2006. Seleção de leveduras da Região Amazônica para produção de protease extracelular. Acta Amazonica. 36(3): 299-306.

OLIVEIRA, LDR 2013. Plantas medicinais como alternativa para o controle de Haemonchus contortus em ovinos: testes in vitro e in vivo. xiii, 59 f., il. Dissertação de mestrado em Ciências Animais, Universidade de Brasília, Brasília, Brasil

ONOFRE, SB., CUZZI1, C., LINK, S., VILANI, A 2015. Enzimas extracelulares produzidas por fungos endofíticos isolados de Baccharis dracunculifolia D.C. (Asteraeceae). Gl. Sci. Technol., v. 04, n. 02, p. 47 - 57.

ORLANDELLI, RC., DE ALMEIDA, TT., ALBERTO, RN,, POLONIO, JC., AZEVEDO, JL., PAMPHILE, JA 2015. Atividades antifúngicas e proteolíticas de fungos endofíticos isolados de Piper hispidum Sw. Braz J Microbiol. 46 (2): 359-66.

PAMPHILE, JA, et al. 2017. Biotechnological applications of secondary metabolites extracted from endophytic fungi: the case of Colletotrichum sp. Rev. Uningá. 53: 113-119.

PIMENTA, RS., ALVES, PD., ALMEIDA, GM., SILVA, JF., MORAIS, PB,, CORRÊA, AJR., ROSA, CA 2009. Comunidades de leveduras em dois fragmentos de Mata Atlântica no Sudeste do Brasil. Braz J Microbiol. 40 (1): 90-95.

PELLICCIA, C., ANTONIELLI, L., CORTE, L., BAGNETTI, A., FATICHENTI, F., CARDINALI, G 2011. Preliminary prospection of the yeast biodiversity on apple and pear surfaces from Northern Italy orchards. Ann. Microbiol. 61 (4): 965-972.

PIOMBO, E., ABDELFATTAH, A., DANINO, Y., SALIM, S., FEYGENBERG, O., SPADARO, D., WISNIEWSKI, M., \& DROBY, S 2020. Characterizing the Fungal Microbiome in Date (Phoenix dactylifera) Fruit Pulp and Peel from Early Development to Harvest. Microorganisms. 8(5), 641-656.

PATRULEA, V., YOUNES, I., JORDAN, O., BORCHARD, G 2019. ChitosanBased Systems for Controlled Delivery of Antimicrobial Peptides for Biomedical Application. Jana S., Jana S. (eds) Functional Chitosan. Springer, Cingapura. 8: 415-455.

PRETORIUS, IS 2000. Tailoring wine yeast for the new millennium: novel approaches to the ancient art of winemaking. Yeast. 16(8):675-729.

PROMPUTTHA, I, et al. 2010. Can leaf degrading enzymes provide evidence that endophytic fungi becoming saprobes?. Fungal Diversity. 41(1): 89-99.

REIS, AF, et al. 2019. Characteristics and potentialities of Savanna fruits in the food industry. Braz. Jornal Food Technol. 22: 1-12. 
ROCHA, M. S. Compostos bioativos e atividade antioxidante (in vitro) de frutos do cerrado piauiense. Teresina, 2011. 93p. Dissertação (Mestrado)Universidade Federal do Piauí- UFPI.

SAND,RI DO, et al. 2017. Antioxidant activity and physicochemical characteristics of buriti pulp (Mauritia flexuosa) collected in the city of Diamantino - MTS1. Rev. Bras. Frutic. 39(3): 1-7.

SCHULZ, B \& BOYLE, C 2005. The endophytic continuum. Mycological research. 109(6): 661-686.

SILVA, M. R., LACERDA, D. B. C. L., SANTOS, G. G., \& MARTINS, D. M D. O. Caracterização química de frutos nativos do cerrado. Ciência Rural, 38(6), 1790-1793, 2008

SILVA, MHR 2017. Fungos endofíticos associados à Passiflora incarnata e avaliação de seu potencial biotecnológico. Dissertação (Mestrado em Ciências Biológicas)-Universidade Estadual Paulista, São Paulo, Brasil.

SILVA, FA, et al. 2018. Diversity of cultivable fungal endophytes in Paullinia cupana (Mart.) Ducke and bioactivity of their secondary metabolites. Rev. PLoS One. 13(4): 1-34.

SOUZA, LS 2011 Nematóides ciatostomíneos: Avaliação do desenvolvimento de ovos em baixas temperaturas e efeito de extratos de plantas sobre as fases pré-parasíticas. Dissertação (Mestrado em Ciências Veterinárias) Universidade de Seropédica, Rio de Janeiro, Brasil.

SPERANDIO, EM., VALE, HMM., \& MOREIRA, GAM 2015. Yeasts from native Brazilian Cerrado plants: Occurrence, diversity and use in the biocontrol of citrus green mould. Fungal Biol. 119: 984-993.

THIEMANN, JE 1980. Produção de celulases e hidrólise enzimática de resíduos celulósicos. Fermentações Industriais e Transformações Microbianas no solo. Sociedade Brasileira de Microbiologia, São Paulo, p. 168-185.
TRINDADE, RC., RESENDE, MA., SILVA, CM., ROSA, CA 2002. Yeasts associated with fresh and frozen pulps of Brazilian tropical fruits. Syst Appl Microbiol. 25(2):294-300.

TRINDADE RC, et al. 2004. Candida sergipensis, a new asexual yeast species isolated from frozen pulps of tropical fruits. Antonie van Leeuwenhoek. 86. 27-32.

U'REN, JM., LUTZONI, F., MIADLIKOWSKA, J., LAETSCH, AD., ELIZABETH AA 2012. Host and geographic structure of endophytic and endolichenic fungi at a continental scale. American Journal of Botany. 99: 898-914.

VADKERTIOVÁ, R., MOLNÁROVÁ, J., VRÁNOVÁ, D., SLÁVIKOVÁ, E 2012. Yeasts and yeast-like organisms associated with fruits and blossoms of different fruit trees. Can J Microbiol. 58(12):1344-1352.

WANG, LW., ZHANG, YL., LIN, FC., HU, YZ., ZHANG, CL 2011. Natural products with antitumor activity from endophytic fungi. Mini Rev Med Chem. 11(12):1056-1074.

YANG X, et al. 2013. Extracellular enzyme production and phylogenetic distribution of yeasts in wastewater treatment systems. Bioresource technology. 129: 264-273.

YANG, XL., ZHANG, JZ., LUO, DQ. 2012. The taxonomy, biology and chemistry of the fungal Pestalotiopsis genus. Nat Prod Rep. 29(6): 622-641.

Received: 18/01/2021

Revised: 09/07/2021

Accepted: 21/07/2021

Published online: 27/08/2021 